\title{
Assessment of cadmium tolerance and phytoextraction ability in young Populus deltoides L. and Populus $\times$ euramericana plants through morpho-anatomical and physiological responses to growth in cadmium enriched soil
}

\author{
Nataša Nikolić (1), \\ Lana Zorić (1), \\ Ivana Cvetković (1), \\ Slobodanka Pajević (1), \\ Milan Borišev ${ }^{(1)}$, \\ Saša Orlović (2), \\ Andrej Pilipović (2)
}

\begin{abstract}
Fast growing woody plants represent effective tools for cadmium (Cd) extraction during remediation of low to medium $\mathrm{Cd}$ contaminated soils. Poplars are good candidates for this task because of their rapid growth rate, high biomass yield, and adaptability, as well as the availability of well-characterized clones/ genotypes with various anatomical and physiological traits. The present study evaluates the potential of Populus deltoides (clone B-81) and Populus $\times$ euramericana (clone Pannonia) for phytoremediation of $\mathrm{Cd}$ contamination in soil. Poplar clones were analyzed for (1) plant growth response to $\mathrm{Cd}$ contamination, (2) Cd accumulation, translocation, and partitioning between plant organs, and (3) morphological, anatomical and physiological responses to $\mathrm{Cd}$ stress as a function of biomass production. Plants were cultivated in soil moderately contaminated with $\mathrm{Cd}\left(8.14 \mathrm{mg} \mathrm{kg}^{-1}\right.$ soil) under semi-controlled conditions for six weeks. Our results suggest that $P$. $\times$ euramericana and $P$. deltoides clones respond differently to $\mathrm{Cd}$ contamination. Biomass production and morphological characteristics were more negatively affected in $P$. $\times$ euramericana than in $P$. deltoides plants. However, most examined leaf structural parameters were not significantly affected by $\mathrm{Cd}$. In most cases, photosynthetic characteristics and gas exchange parameters were affected by $\mathrm{Cd}$ treatment, but the levels and patterns of changes depended on the clone. High tolerance to applied $\mathrm{Cd}$ levels, as estimated by the tolerance index, was observed in both clones, but was higher in $P$. deltoides than $P . \times$ euramericana $(82.2 \mathrm{Vs}$. 66.5, respectively). We suspect that the higher tolerance to $\mathrm{Cd}$ toxicity observed in $P$. deltoides could be related to unchanged proline content and undisturbed nitrogen metabolism. Following treatment, 58.0 and $46.7 \%$ of the total $C d$ content was accumulated in the roots of $P$. $\times$ euramericana and $P$. deltoides, respectively, with the remainder in the stems $(18.2$ and $39.9 \%)$ and leaves $(23.8$ and $13.4 \%)$. In summary, $P$. deltoides displayed better phytoextraction performance under $C d$ exposure than $P . \times$ euramericana, suggesting its potential not only for Cd phytostabilization, but also phytoextraction proj-
\end{abstract} ects.

Keywords: Cadmium, Phytoextraction, Poplars, Tolerance, Toxicity

tant due to its high toxicity for all living organisms (Sarwar et al. 2010). Widespread sources of $\mathrm{Cd}$ release, such as mining, cultivation of plants for energy production and

\section{Introduction}

Cadmium (Cd) is a non-essential heavy metal for plants, and is commonly considered to be an extremely significant pollu- agricultural activities, have caused vast areas of land to become unproductive and even hazardous for wildlife and humans, and have diminished the availability of arable land. Furthermore, crop plants can accumulate and translocate contaminants such as Cd in edible parts (Nazar et al. 2012, Liu et al. 2016). Because of this, European Union regulatory legislation has set the recommended upper limit for Cd contamination in agricultural soil at $3 \mu \mathrm{g} \mathrm{g}^{-1}$ (European Union 2002). Thus, development of methods for efficient removal of toxic elements, such as $\mathrm{Cd}$ from contaminated soil is necessary for prevention of $\mathrm{Cd}$ transfer into the human food chain. As an alternative to conventional methods, various phytoremediation techniques have been proposed employing woody plant species to either remove pollutants from contaminated soils or render them harmless (To- 
gnetti et al. 2013). One of these techniques, referred to as phytoextraction, involves the use of plants for extraction of heavy metals from contaminated soils, and appears to be a promising method for remediation of low to medium levels of soil contamination. Importantly, phytoextraction of low to medium concentrations of heavy metals does not significantly disturb plant morpho-physiological processes, allowing normal growth and development, i.e., production of biomass coupled with soil decontamination.

Along with other fast growing tree species, poplars are considered to be multifunctional trees, displaying potential for environmental restoration and land reclamation, together with high biomass production convenient for bioenergy or paper production (Tognetti et al. 2013).

Reliable evaluation of heavy metal tolerance and phytoremediation potential in poplar species should be conducted by screening the physiological and morphological characteristics of plants exposed to the contaminant metal of interest in the soil. Plant growth, gas exchange parameters (photosynthetic rate, stomatal conductance, substomatal $\mathrm{CO}_{2}$ concentration), chlorophyll content and chlorophyll $a$ fluorescence parameters are often used as indicators of possible disturbances triggered by heavy metal contamination (Bernardini et al. 2016a, 2016b). In addition, the rate of photosynthesis has often been correlated with biomass production, and thus might be used as an indicator of the growth potential of tree species and genotypes under pollutant exposure. $\mathrm{Cd}$ causes structural and functional alterations in photosynthetic apparatus, resulting in reduced or inhibited photosynthesis (Parmar et al. 2013). Furthermore, Cd toxicity may provoke an increase in peroxidation of chloroplast membrane lipids by enhancement of lipoxygenase activity, resulting in disorganization of thylakoid membranes and decreased concentration of both chlorophylls and carotenoids (Djebali et al. 2005). High $\mathrm{Cd}$ concentrations in plant tissues can also affect other physiological processes, such as water regime, mineral nutrient uptake and ion metabolism (Parmar et al. 2013). Optimal supply of nitrogen and other mineral nutrients could alleviate Cd-induced toxic effects in plants by enhancing bio-

Tab. 1 - Physico-chemical characteristics of soil in the seedling nursery.

\begin{tabular}{|c|c|}
\hline Characteristic & Value \\
\hline Coarse sand(\%) & 0.6 \\
\hline Find sand(\%) & 76.4 \\
\hline Powder(\%) & 13.2 \\
\hline Clay(\%) & 9.88 \\
\hline in $\mathrm{KCl}$ & 7.57 \\
\hline in $\mathrm{H}_{2} \mathrm{O}$ & 8.45 \\
\hline $\mathrm{CaCO}_{3}(\%)$ & 17.25 \\
\hline Humus(\%) & 1.48 \\
\hline Total N(\%) & 0.12 \\
\hline
\end{tabular}

chemical reactions and physiological processes, along with reduced $\mathrm{Cd}$ accumulation (Nazar et al. 2012).

Inhibition of nitrate reductase (NR) activity in plants experiencing $\mathrm{Cd}$ toxicity leads to reduced nitrate assimilation (Asgher et al. 2013) and nitrogen deficiency. In order to obtain the nitrogen necessary for the synthesis of other organic compounds under conditions of $\mathrm{N}$ deficiency, degradation of proline is favored by stimulation of proline dehydrogenase activity, resulting in production of glutamate utilized as a nitrogenous source for the synthesis of other amino acids (Dandekar \& Uratsu 1988). Furthermore, proline alleviates heavy metal stress in plants through direct metal binding, as well as enhancement of antioxidant signaling and defenses (Sharma \& Dietz 2006).

There is little information in the literature on the role of leaf anatomic structure in photosynthetic performance under heavy metal stress (Shi \& Cai 2008). In spite of structural and ultrastructural changes to leaf lamina, photosynthetic balance and biomass production in $P$. deltoides might be sustained by the fact that photosynthetic pigment concentrations remain unchanged under heavy metal stress (Stoláriková-Vaculíková et al. 2015). Thicknesses of the spongy and palisade parenchyma are associated with biomass production and could be used as indicators of growth potential in poplars (Al Afas et al. 2007). Therefore, the interrelation between micromorphological parameters together with physiological and biochemical characteristics is necessary for identification of plants suitable for phytoremediation (Luković et al. 2012).

The present study was designed to evaluate the phytoremediation potential of six week old Populus $\times$ euramericana and Populus deltoides plants cultivated under semi controlled conditions, in pots containing soil artificially contaminated with $\mathrm{Cd}$. Poplar clones were analyzed for: (1) plant growth response to $\mathrm{Cd}$ contamination; (2) Cd accumulation, translocation, and partitioning between plant organs; and (3) morphological, anatomical and physiological responses to $\mathrm{Cd}$ stress as a function of biomass production. Obtained results may be used as reliable guidelines in selection of genotypes with high Cd tolerance and phytoremediation potential for efficient use in projects aimed at reclamation of $\mathrm{Cd}$ polluted sites.

\section{Material and methods}

\section{Plant material and cultivation} conditions

Soil pot culture experiments were conducted in a greenhouse (semi-controlled conditions) at the Department of Biology and Ecology, Faculty of Sciences, University of Novi Sad, Republic of Serbia. The temperature range was $18 / 30{ }^{\circ} \mathrm{C}$ (night/ day) and illumination was natural and de- pendent on outside light conditions. Relative air humidity ranged from 70 to $80 \%$. Two poplar clones were selected from an assortment established at the Institute of Lowland Forestry and Environment (Novi Sad, Republic of Serbia): Populus deltoides (clone B-81) and a hybrid poplar Populus $x$ euramericana (clone Pannonia). The seedling nursery is located in the Panonian plane in northern Serbia $\left(45^{\circ} 18^{\prime} 15^{\prime \prime} \mathrm{N}, 19^{\circ}\right.$ $\left.56^{\prime} 31^{\prime \prime} \mathrm{E}\right)$. Dormant hardwood cuttings of both poplar clones were collected from one-year-old shoots in the beginning of February, and kept in a cool chamber until use. Soil (fine sandy loam) was collected from the seedling nursery $(0-20 \mathrm{~cm}$ depth) and its physico-chemical properties are presented in Tab. 1. One month prior to planting, dry soil was sieved and enriched with cadmium by spraying aqueous solution of $\mathrm{CdCl}_{2} \cdot \mathrm{H}_{2} \mathrm{O}$, and thoroughly mixed (the experiment was set up in May). For both clones, two treatments - (1) control, o mg $\mathrm{kg}^{-1}$ of Cd; (2) Cd treatment, $8.14 \mathrm{mg} \mathrm{kg}^{-1}$ of $\mathrm{Cd}$ - were set up with four replicates (pots). Hardwood cuttings were soaked in water for $24 \mathrm{~h}$ before use. Six cuttings (20 $\mathrm{cm}$ long of similar diameter) were planted in a single pot, containing $5 \mathrm{I}$ of either $\mathrm{Cd}$ free (control) or Cd-enriched soil. During the cultivation period, plants were allowed to develop only one sprout per cutting, by cutting off extra sprouts. Soil moisture was maintained between 60 and $80 \%$ of soil water capacity throughout the experimental period using tap water. Three weeks after planting, $0.2 \mathrm{I}$ of full-strength Hoagland nutrient solution was added to the pots. After 6 weeks of cultivation, the morphological and physiological traits of both clones were measured, prior to harvesting for chemical analysis. The fifth fully-expanded leaf (counted from the apex of the shoot) was used for either in vivo or in vitro measurements of physiological parameters, as well as structural characteristics of leaf lamina. Ten leaves were sampled from all plants in the same treatment group within a clone for analysis of structural characteristics. Other leaves of the same age were collected and pooled to obtain a representative sample used for determination of photosynthetic pigments, proline concentration, nitrate reductase activity and chemical analyses.

\section{Growth parameters}

Shoots were immediately harvested after determination of physiological parameters, and leaves were separated from stems. Roots were carefully separated from the soil and gently washed using tap and deionized water. The total leaf area was measured using a portable leaf area meter ( $\mathrm{Li}$ Cor $3000^{\circledast}$, Lambda Instruments Corporation, Lincoln, NE, USA). Fresh weight of leaves, roots and stems, as well as stem height and basal diameter $(1 \mathrm{~cm}$ above the insertion to the rooted cutting) were measured, and samples were completely dried $\left(80{ }^{\circ} \mathrm{C}, 48 \mathrm{~h}\right)$ and milled (A11 basic, IKA ${ }^{\oplus}$, 
Werke, Germany). Biomass production and growth parameters of six individual plants was determined for each treatment and each clone $(n=6)$.

\section{Physiological parameters}

Rate of photosynthesis $(\mathrm{Pn})$ and transpiration ( $\mathrm{Tr})$, stomatal conductance $\left(\mathrm{g}_{\mathrm{s}}\right)$, and intercellular concentrations of $\mathrm{CO}_{2}$ (Ci) were determined using a LCpro+ portable photosynthetic system (ADC BioScientific Ltd, Hoddesdon, UK). Light conditions were set using the Lcpro+ light unit to emit photosynthetically active radiation (PAR) at $1000 \mu \mathrm{mol} \mathrm{m} \mathrm{m}^{-2} \mathrm{~s}^{-1}$. A flow of ambient air to the leaf chamber was provided by the air supply unit at a constant rate of 100 $\mu \mathrm{mol} \mathrm{s} \mathrm{s}^{-1}$. Temperature, $\mathrm{CO}_{2}$ concentration, and humidity were at ambient levels. The gas exchange parameters of six individual plants were determined for each treatment and each clone $(n=6)$. After measurement of gas exchange parameters, the same leaves were collected and used for estimation of photosynthetic pigments and proline concentration, as well as for measurement of nitrate reductase activity. Concentration of chlorophylls and carotenoids was determined according to the method of Von Wettstein (1957). Fresh plant material was homogenized with absolute acetone using a pestle and mortar, and the homogenate was filtered. The filtrate was used to measure absorbance spectrophotometrically (Beckman DU $-65^{\circledR}$, Beckman Coulter, Brea, (A, USA) at 662, 644 and $440 \mathrm{~nm}$. Concentrations of photosynthetic pigments were calculated and expressed as $\mathrm{mg} \mathrm{g}^{-1}$ of dry weight. The concentration of free proline was estimated spectrophotometrically using the method of Bates (1973). Plant material was homegenized with $10 \mathrm{ml}$ of $3 \%$ sulfosalicylic acid and the homogenate was filtered. The mixture containing $2 \mathrm{ml}$ of filtrate, $2 \mathrm{ml}$ of glacial acetic acid and $2 \mathrm{ml}$ of acid ninhydrin reagent was incubated in a boiling water bath for 15 minutes. After cooling, four $\mathrm{ml}$ toluene was added to the mixture. Absorbance of the proline-nynhidrin complex extracted in toluene was measured spectrophotometrically (Beckman DU-65) at $520 \mathrm{~nm}$. Proline concentration was expressed as $\mu \mathrm{g} \mathrm{g}^{-1}$ fresh weight. Nitrate reductase (NR) activity was determined using an in vivo method as follows: samples of leaf lamina without the main vein $(0.2 \mathrm{~g})$ were incubated in a buffered medium containing $\mathrm{NO}_{3}$, and the concentration of nitrites produced over time as the product of nitrate reductase activity were measured spectrophotometrically at $520 \mathrm{~nm}$ (Hageman \& Reed 1980). NR activity was calculated using calibration curves, and expressed as $\mu \mathrm{M} \mathrm{NO}_{2}^{-} \mathrm{g}^{-1} \mathrm{~h}^{-1}$. Analysis of photosynthetic pigments and proline concentration, as well as NR activity, was performed in five replicates for each treatment and each clone $(n=5)$.

\section{Structural characteristics of leaf lamina}

Leaves (the fifth leaf from the apex of the shoot) were sampled at the end of the experimental period for each treatment and clone, and fixed in 50\% ethanol. Anatomical parameters were analyzed on samples excised from the section between the third and fourth lateral vein of the lamina and the main vein section. $25 \mu \mathrm{m}$ thick cross sections were made using a Leica $\mathrm{CM}$ $1850^{\circ}$ cryostat (Leica, Wetzlar, Germany) at a temperature of $-20{ }^{\circ} \mathrm{C}$. Measurements were performed by Image Analysing System Motic Images Plus. Relative proportions of adaxial and abaxial epidermis, mesophyll, spongy and palisade tissues were calculated as a ratio versus the full lamina thickness (taken as 100\%). The main vein index was calculated as follows: leaf blade thickness at the main vein/leaf blade thickness at $1 / 4$ of the leaf blade width.

\section{Chemical analysis of plant samples}

After biomass measurements, leaves, stems and roots were oven-dried at $80{ }^{\circ} \mathrm{C}$ until a constant weight was obtained. Plant samples were digested with $\mathrm{HNO}_{3}$ using a closed vessel microwave digestion system (Milestone D series Microwave Digestion System, Milestone Inc, Shelton, CT, USA). Concentrations of $\mathrm{Cd}$ were determined by employing flame atomic absorption spectrophotometry (AAS240FS ${ }^{\circledR}$, Varian Medical Systems Inc, Palo Alto, CA, USA). Analyses of plant samples were performed in tripli- cate $(n=3)$ for each treatment and each clone. $\mathrm{Cd}$ concentrations in leaves, stems and roots $\left(\mu \mathrm{g} \mathrm{g}^{-1}\right)$ were calculated on the basis of dry weight as follows: reading ( $\mu \mathrm{g}$ $\left(\mathrm{d} \mathrm{ml} \mathrm{l}^{-1}\right) \times$ dilution factor $(\mathrm{ml}) /$ dry weight (g).

\section{Calculations and statistical analysis}

In order to estimate poplar clone performance and phytoremediation potential, tolerance index ( $\mathrm{Ti}$ - Wilkins 1978), biological concentration (BCF) and translocation (Tf) factors (Zhang et al. 2014b) for individual plant organs were calculated. Tolerance index was calculated as follows: fresh weight of plants treated with $\mathrm{Cd} \times 100 /$ fresh weight of control plants. Biological concentration factor for leaves, stems and roots were evaluated as the ratio of $\mathrm{Cd}$ concentration in plant organs to $\mathrm{Cd}$ concentration in soil. Translocation of $\mathrm{Cd}$ from roots to leaves and stems (Tf) was calculated as follows: concentration of $\mathrm{Cd}$ in leaves or stems/concentration of $\mathrm{Cd}$ in the root. Obtained data were calculated and statistically processed using Microsoft Office Excel $^{\circledast}$ and STATISTICA ${ }^{\circledast}$ for Windows ver. 12.0 (StatSoft, Tulsa, OK, USA). Independent $t$-test or Duncan's test were used to compare the mean values of studied parameters obtained for control and treated plants, within or between individual clones. A two-way analysis of variance (ANOVA) was performed to detect significance levels ( $P$ values) for effects of clone, treatment and their interactions. Relationships between morphological, anatomical and physiological parameters, $\mathrm{Cd}$ accumulation, and biomass production in poplar plants treated with $\mathrm{Cd}$ were evaluated by Pearson's correlation coefficient.

\section{Results and discussion}

In the present study we investigated morpho-physiological responses and leaf structural characteristics of two poplar clones cultivated in soil moderately contaminated with $\mathrm{Cd}$, in order to estimate their performance and phytoextraction potential.

Biomass production and plant tolerance Previous investigations had commonly re-

Tab. 2 - Plant growth and tolerance indices (Ti) in Populus $\times$ euramericana and P. deltoides plants cultivated in soil culture without (control) or with (Cd treat) $\mathrm{Cd}$. Values are mean \pm standard error. Means within a row followed by different letters are significantly different after Duncan's test $(P \leq 0.05)$. Two-way ANOVA $(n=6)$ was applied to evaluate the coefficient of variation $(C V, \%)$, the clone effect, the Cd treatment effect (Cd treat) and their interaction (Clone $\times C d) .(*): p<0.05 ;(* *): p<0.01 ;(* * *): p<0.001 ;(n s): p>0.05$.

\begin{tabular}{|c|c|c|c|c|c|c|c|c|}
\hline \multirow[b]{2}{*}{ Parameter } & \multicolumn{2}{|c|}{ Populus $\times$ euramericana } & \multicolumn{2}{|c|}{ P. deltoides } & \multirow{2}{*}{$\begin{array}{l}\text { CV } \\
(\%)\end{array}$} & \multicolumn{3}{|c|}{ ANOVA $P$ value } \\
\hline & Control & $\underset{\text { treat }}{\mathrm{Cd}}$ & Control & $\underset{\text { treat }}{\mathrm{Cd}}$ & & Clone & $\underset{\text { treat }}{\mathrm{Cd}}$ & $\begin{array}{l}\text { Clone } \\
\times \mathrm{Cd}\end{array}$ \\
\hline Total biomass (g) & $7.86 \pm 0.10^{a b}$ & $5.23 \pm 0.06^{c}$ & $9.21 \pm 0.50^{a}$ & $7.53 \pm 0.69^{b}$ & 9.97 & $* *$ & ** & ns \\
\hline Root mass $(\mathrm{g})$ & $0.70 \pm 0.07^{a}$ & $0.30 \pm 0.02^{b}$ & $0.85 \pm 0.07^{a}$ & $0.48 \pm 0.04^{b}$ & 15.94 & * & $* * *$ & ns \\
\hline Shoot mass(g) & $1.81 \pm 0.08^{a}$ & $1.45 \pm 0.14^{\mathrm{a}}$ & $1.72 \pm 0.24^{a}$ & $1.33 \pm 0.27^{a}$ & 21.81 & ns & ns & ns \\
\hline Leaf mass (g) & $5.36 \pm 0.20^{b}$ & $3.47 \pm 0.15^{c}$ & $6.65 \pm 0.25^{a}$ & $5.72 \pm 0.44^{b}$ & 9.21 & $* * *$ & $* *$ & ns \\
\hline Shoot height $(\mathrm{cm})$ & $27.00 \pm 0.29^{a}$ & $27.90 \pm 1.30^{a}$ & $23.00 \pm 1.15^{b}$ & $15.53 \pm 1.43^{c}$ & 8.42 & $* * *$ & * & $* *$ \\
\hline Number of leaves & $19.33 \pm 0.33^{a}$ & $17.67 \pm 0.33^{a}$ & $12.67 \pm 0.33^{b}$ & $14.33 \pm 0.88^{b}$ & 5.7 & $* * *$ & ns & * \\
\hline Leaf area $\left(\mathrm{cm}^{2}\right)$ & $333.58 \pm 27.62^{a b}$ & $280.05 \pm 15.22^{b}$ & $344.18 \pm 22.72^{\mathrm{ab}}$ & $368.25 \pm 13.50^{a}$ & 10.75 & * & ns & ns \\
\hline $\mathrm{Ti}(\%)$ & $100.00 \pm 0.00^{a}$ & $66.50 \pm 0.38^{c}$ & $100.00 \pm 0.00^{a}$ & $82.19 \pm 7.95^{b}$ & 7.91 & ns & $* * *$ & ns \\
\hline
\end{tabular}


Tab. 3 - Pearson's correlation coefficients between biomass production and morphological, leaf anatomical and physiological characteristics, and $\mathrm{Cd}$ accumulation in Populus $\times$ e euramericana and $P$. deltoides plants under $C d$ exposure. (Ti): tolerance index; $\left(\mathrm{Cd}_{\text {roots }}, \mathrm{Cd}_{\text {stem }}, \mathrm{Cd}_{\text {leaves }}\right)$ : concentration of $\mathrm{Cd}$ in roots, stems and leaves, respectively;

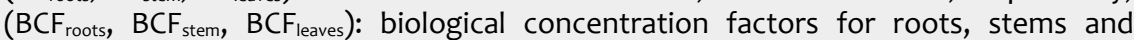
leaves, respectively; $\left(\mathrm{Tf}_{\text {stem }}, \mathrm{Tf}_{\text {leaves }}\right)$ : translocation factors for stem and leaves, respectively; $(*): \mathrm{p}<0.05 ;(* *): \mathrm{p}<0.01 ;(* * *): \mathrm{p}<0.001$

\begin{tabular}{|c|c|c|}
\hline \multirow{2}{*}{ Parameters } & \multicolumn{2}{|c|}{ Biomass Production } \\
\hline & P. $\times$ euramericana & P. deltoides \\
\hline Root mass & $0.9148^{*}$ & 0.6978 \\
\hline Shoot mass & 0.7271 & $0.9426^{* *}$ \\
\hline Number of leaves per plant & $0.8692^{*}$ & -0.1947 \\
\hline Leaf area per plant & 0.6711 & -0.4792 \\
\hline Leaf mass per plant & $0.9798^{* *}$ & $0.9769^{* *}$ \\
\hline $\mathrm{Ti}$ & $0.9958^{* * *}$ & $0.8477^{*}$ \\
\hline Lamina thickness & -0.3543 & 0.2070 \\
\hline Palisade/spongy tissue ratio & $0.9783^{* *}$ & -0.7756 \\
\hline Mesophyll thickness & -0.5589 & 0.2523 \\
\hline Adaxial epidermis thickness & 0.4731 & 0.0644 \\
\hline Abaxial epidermis thickness & -0.2922 & 0.7487 \\
\hline Palisade tissue thickness & $0.8414^{*}$ & $0.8275^{*}$ \\
\hline Spongy tissue thickness & -0.6422 & 0.4079 \\
\hline Main vein cross section area & $-0.9636^{* *}$ & 0.4103 \\
\hline Main vein height/lamina thickness & $-0.8966^{*}$ & -0.2503 \\
\hline Main vein vascular bundle cross section area & $-0.9252^{* *}$ & 0.5129 \\
\hline Main vein vascular bundle vessel lumen area & $-0.8218^{*}$ & 0.6048 \\
\hline Adaxial epidermis cell cross section area & $-0.9566^{* *}$ & 0.6386 \\
\hline Palisade tissue cell cross section area & $0.9753^{* *}$ & $-0.8145^{*}$ \\
\hline Spongy tissue cell cross section area & -0.1765 & -0.3400 \\
\hline Abaxial epidermis cell cross section area & $0.8252^{*}$ & -0.0726 \\
\hline Rate of photosynthesis $(\mathrm{Pn})$ & $0.9952^{* * *}$ & $0.8486^{*}$ \\
\hline Rate of transpiration (Tr) & $0.9830^{* * *}$ & 0.7723 \\
\hline Stomatal conductance $\left(\mathrm{g}_{\mathrm{s}}\right)$ & $0.9862^{* * *}$ & 0.5887 \\
\hline Intercellular $\mathrm{CO}_{2}$ concentration $(\mathrm{Ci})$ & $-0.8919^{*}$ & -0.3199 \\
\hline Chlorophyll $a$ & 0.7859 & 0.7369 \\
\hline Chlorophyll $b$ & $0.9867^{* * *}$ & 0.7128 \\
\hline Chlorophyll $a+b$ & $0.8954^{*}$ & 0.7043 \\
\hline Carotenoids & 0.6920 & 0.7188 \\
\hline Chlorophyll $a / b$ & $-0.9477^{* *}$ & -0.6709 \\
\hline Concentration of proline & $0.9598^{* *}$ & 0.1875 \\
\hline Activity of nitrate reductase & $0.9697^{* *}$ & 0.3073 \\
\hline$C d_{\text {leaves }}$ & $-0.9933^{* * *}$ & -0.8045 \\
\hline $\mathrm{Cd}_{\text {roots }}$ & $-0.9969^{* * *}$ & -0.6228 \\
\hline $\mathrm{Cd}_{\text {stem }}$ & $-0.9775^{* *}$ & -0.7247 \\
\hline $\mathrm{BCF}_{\text {leaves }}$ & $0.9901^{* * *}$ & 0.6438 \\
\hline $\mathrm{BCF}_{\text {roots }}$ & $0.9935^{* * *}$ & 0.7052 \\
\hline $\mathrm{BCF}_{\text {stem }}$ & $0.9757^{* *}$ & 0.6934 \\
\hline$T f_{\text {leaves }}$ & $0.9224^{* *}$ & -0.7221 \\
\hline $\mathrm{Tf}_{\text {stem }}$ & $0.9565^{* *}$ & -0.7647 \\
\hline
\end{tabular}

ported stunted growth of roots and stems as an effect of Cd toxicity in plants, because of the tight relationships between biomass production and changes in photosynthetic activity, root characteristics, mineral elements and plant water supplies. Growth parameters of the poplar genotypes included in the present study are presented in Tab. 2. Two-way ANOVA results suggest that most of the growth parameters were affected by clone and Cd treatment. However, the genotypes differently responded to $\mathrm{Cd}$ treatment with respect to stem height and diameter. Total biomass, as well as the mass of leaves and roots, was significantly reduced in plants exposed to $\mathrm{Cd}$ with respect to control, resulting in a decrease of $\mathrm{Ti}$ in both genotypes. In both clones, the obtained results suggest that root growth was more negatively affected by $\mathrm{Cd}$ than shoot growth. However, reduced root biomass was more evident in
Populus $\times$ euramericana than in P. deltoides plants, probably due to higher accumulation of $\mathrm{Cd}$ in Populus $\times$ euramericana vs. $P$. deltoides. Decreased root growth, along with other Cd-induced alterations, limit the potential of roots to absorb water and mineral elements, leading to inhibition of photosynthesis and transpiration (Chaffei et al. 2004, Lux et al. 2011).

To evaluate the ability of the studied poplar clones to tolerate $\mathrm{Cd}$ soil contamination, Ti was calculated (Tab. 2). Although Ti was negatively affected by $\mathrm{Cd}$ treatment in both clones, P. deltoides plants showed higher tolerance to applied $\mathrm{Cd}$ levels than Populus $\times$ euramericana. Estimated values of $\mathrm{Ti}$ (66.5 and 82.2 in Populus $\times$ euramericana and $P$. deltoides, respectively) were greater than 60 for both clones, indicating a high tolerance to the applied $\mathrm{Cd}$ levels (Lux et al. 2004).

In an attempt to identify a reliable indica- tor of good productivity in $\mathrm{Cd}$ stressed poplars, we correlated biomass production with some morphological, structural and physiological characteristics in Populus $x$ euramericana and $P$. deltoides plants (Tab. 3). Significant positive correlation was recorded between biomass and the rate of photosynthesis, mass of leaves (per plant) and palisade tissue thickness in both poplar clones. In addition to the above characteristics, in the less tolerant Populus $\times$ euramericana clone, biomass production was significantly (positively or negatively) correlated with numerous other characteristics under $\mathrm{Cd}$ exposure. Recently, Aasamaa et al. (2010) found that biomass production of Salix plants grown in a wastewater purification system correlated more strongly with photosynthetic characteristics than with plant water relations. According to the results of our experiments, the rate of photosynthesis might be considered to be a reliable, easy-to-measure indicator of high biomass production in poplars under heavy metal stress.

\section{Leaf anatomical characteristics}

In plants exposed to heavy metals, alterations to leaf structural parameters might affect photosynthesis, and thus biomass production and plant performance under stress conditions. The structural characteristics of leaves in $P$. deltoides and $P . \times$ euramericana plants cultivated with or without moderate levels of $\mathrm{Cd}$ in the soil are presented in Tab. 4. Although leaf lamina thickness did not differ significantly among poplar clones, values measured for relative mesophyll thickness, main vein characteristics (cross section area, vascular bundle and vessel lumen area, index), and the cross section area of spongy tissue and abaxial epidermis cells were considerably lower in Populus $\times$ euramericana than P. deltoides plants grown under control conditions (Fig. 1). Cd did not considerably affect most of the studied leaf structural parameters, with the exception of the cross section area of adaxial epidermis cells and vessel lumen area in Populus $\times$ euramericana, and the cross section area of palisade tissue cells in both poplar clones. The thickness of spongy tissue was greater than the thickness of palisade tissue in both clones, regardless of $\mathrm{Cd}$ exposure. These findings are in agreement with results obtained for other poplar genotypes from different taxa (Al Afas et al. 2007).

Well documented relationships between structural and functional characteristics of leaf mesophyll indicate that changes in internal leaf morphology affect the photosynthetic process (Ivanova \& P'yankov 2002). In the present study, palisade cell size was considerably but differentially changed in both clones under $\mathrm{Cd}$ exposure: palisade cell size was decreased in Populus $x$ euramericana but increased in $P$. deltoides. In a hydroponic experiment with Populus $\times$ euramericana (clone 1-214) and Salix fragilis L., Luković et al. (2012) reported no 
Tab. 4 - Leaf anatomical parameters in Populus $\times$ euramericana and P. deltoides plants cultivated in soil culture without (control) or with ( $\mathrm{Cd}$ treat) $\mathrm{Cd}$. Values are mean \pm standard error. Means within a row followed by different letters are significantly different after Duncan's test ( $\mathrm{P} \leq 0.05$. Two-way ANOVA was applied to evaluate coefficient of variation ( $\mathrm{CV}$, \%), the clone effect, the Cd treat ment effect (Cd treat) and their interaction (Clone $\times C d) .(*): p<0.05 ;(* *): p<0.01 ;(* * *): p<0.001 ;(n s): p>0.05$.

\begin{tabular}{|c|c|c|c|c|c|c|c|c|c|}
\hline \multirow[b]{2}{*}{ Group } & \multirow[b]{2}{*}{ Parameter } & \multicolumn{2}{|c|}{ Populus $\times$ euramericana } & \multicolumn{2}{|c|}{ P. deltoides } & \multirow{2}{*}{$\begin{array}{l}\text { CV } \\
(\%)\end{array}$} & \multicolumn{3}{|c|}{ ANOVA $P$ value } \\
\hline & & Control & $\begin{array}{l}\text { Cd } \\
\text { treat }\end{array}$ & Control & $\begin{array}{l}\text { Cd } \\
\text { treat }\end{array}$ & & Clone & $\begin{array}{l}\text { Cd } \\
\text { treat }\end{array}$ & $\begin{array}{l}\text { Clone } \\
\times \text { Cd }\end{array}$ \\
\hline - & Lamina thickness $(\mu \mathrm{m})$ & $141.70 \pm 6.57^{\mathrm{a}}$ & $143.40 \pm 4.15^{\mathrm{a}}$ & $158.90 \pm 5.19^{\mathrm{a}}$ & $148.80 \pm 6.49^{\mathrm{a}}$ & 8.58 & ns & ns & ns \\
\hline \multirow{5}{*}{$\begin{array}{l}\text { Relative } \\
\text { proportion } \\
(\%) \text { of }\end{array}$} & Mesophyll thickness & $80.60 \pm 1.29^{b}$ & $83.40 \pm 0.99^{a b}$ & $86.10 \pm 0.48^{a}$ & $85.70 \pm 0.56^{a}$ & 2.38 & $* * *$ & ns & ns \\
\hline & $\begin{array}{l}\text { Adaxial epidermis } \\
\text { thickness }\end{array}$ & $9.70 \pm 0.55^{\mathrm{a}}$ & $8.70 \pm 0.43^{a b}$ & $7.30 \pm 0.27^{c}$ & $7.60 \pm 0.39^{b c}$ & 11.36 & *** & ns & ns \\
\hline & $\begin{array}{l}\text { Abaxial epidermis } \\
\text { thickness }\end{array}$ & $7.50 \pm 0.20^{a}$ & $7.50 \pm 0.21^{\mathrm{a}}$ & $6.60 \pm 0.26^{b}$ & $6.30 \pm 0.21^{b}$ & 7.19 & $* * *$ & ns & ns \\
\hline & Palisade tissue thickness & $37.60 \pm 0.64^{\mathrm{ab}}$ & $35.00 \pm 1.00^{b}$ & $38.40 \pm 0.83^{\mathrm{ab}}$ & $38.70 \pm 1.52^{\mathrm{a}}$ & 6.27 & * & ns & ns \\
\hline & Spongy tissue thickness & $43.60 \pm 2.10^{a}$ & $45.20 \pm 1.26^{\mathrm{a}}$ & $46.40 \pm 1.07^{\mathrm{a}}$ & $46.50 \pm 1.92^{\mathrm{a}}$ & 8.10 & ns & ns & ns \\
\hline - & $\begin{array}{l}\text { Palisade/spongy tissue } \\
\text { ratio }\end{array}$ & $0.90 \pm 0.05^{\mathrm{a}}$ & $0.80 \pm 0.04^{a}$ & $0.80 \pm 0.03^{a}$ & $0.80 \pm 0.06^{a}$ & 13.57 & ns & ns & ns \\
\hline \multirow[t]{4}{*}{ Main vein } & Cross section area $\left(\mathrm{mm}^{2}\right)$ & $0.24 \pm 0.03^{b}$ & $0.38 \pm 0.03^{b}$ & $0.78 \pm 0.10^{a}$ & $0.71 \pm 0.09^{a}$ & 29.78 & $* * *$ & ns & ns \\
\hline & Index & $4.40 \pm 0.32^{b}$ & $5.00 \pm 0.25^{b}$ & $6.30 \pm 0.43^{a}$ & $6.80 \pm 0.48^{a}$ & 15.44 & $* * *$ & ns & ns \\
\hline & $\begin{array}{l}\text { Vascular bundle cross } \\
\text { section area }\left(\mathrm{mm}^{2}\right)\end{array}$ & $0.10 \pm 0.01^{\mathrm{b}}$ & $0.14 \pm 0.01^{b}$ & $0.28 \pm 0.03^{\mathrm{a}}$ & $0.26 \pm 0.03^{\mathrm{a}}$ & 24.73 & $* * *$ & ns & ns \\
\hline & $\begin{array}{l}\text { Vascular bundle vessel } \\
\text { area }\left(\mu \mathrm{m}^{2}\right)\end{array}$ & $417.70 \pm 9.68^{\mathrm{b}}$ & $352.00 \pm 32.79^{c}$ & $568.70 \pm 8.77^{\mathrm{a}}$ & $526.80 \pm 10.78^{a}$ & 8.85 & $* * *$ & ns & * \\
\hline \multirow{4}{*}{$\begin{array}{l}\text { Cell } \\
\text { cross- } \\
\text { section } \\
\text { area }\end{array}$} & Adaxial epidermis $\left(\mu \mathrm{m}^{2}\right)$ & $258.30 \pm 11.26^{b}$ & $318.50 \pm 12.18^{a}$ & $229.90 \pm 3.13^{c}$ & $227.50 \pm 3.65^{c}$ & 7.47 & $* * *$ & ** & ** \\
\hline & Palisade tissue $\left(\mu \mathrm{m}^{2}\right)$ & $285.80 \pm 3.91^{\mathrm{b}}$ & $261.40 \pm 0.81^{c}$ & $291.00 \pm 4.13^{b}$ & $313.40 \pm 3.43^{\mathrm{a}}$ & 2.59 & $* * *$ & ns & $* * *$ \\
\hline & Spongy tissue $\left(\mu \mathrm{m}^{2}\right)$ & $205.80 \pm 3.70^{\mathrm{b}}$ & $206.20 \pm 5.29^{b}$ & $269.80 \pm 1.16^{\mathrm{a}}$ & $274.60 \pm 2.98^{a}$ & 0.55 & $* * *$ & ns & ns \\
\hline & Abaxial epidermis $\left(\mu \mathrm{m}^{2}\right)$ & $213.40 \pm 4.18^{\mathrm{b}}$ & $204.10 \pm 2.09^{b}$ & $258.40 \pm 1.14^{\mathrm{a}}$ & $258.60 \pm 3.65^{a}$ & 2.89 & *** & ns & ns \\
\hline
\end{tabular}

significant effect of $\mathrm{Cd}$ treatment on the characteristics of photosynthetic tissue in the poplar clone. However, the percentage of palisade tissue, palisade thickness and cell area increased in Salix fragilis exposed to $\mathrm{Cd}$. In our study, the decrease of palisade cell area observed in the Populus $x$ euramericana clone is in agreement with the findings of Djebali et al. (2005), who reported a reduction of mesophyll cell size, reduced intercellular spaces, and severe alterations of chloroplast fine structure in tomato upon $\mathrm{Cd}$ exposure. Furthermore, Cd treatment affected adaxial epidermis cell size only in the Populus $\times$ euramericana clone. These results are in agreement with the effect of $\mathrm{Cd}$ on dermal tissue in poplar (Luković et al. 2012).
Physiological responses: gas exchange parameters, concentration of photosynthetic pigments, proline accumulation, and NR activity

Undisturbed photosynthesis is necessary for continuous biomass production in plants exposed to heavy metals. Thus, photosynthetic activity is considered an important indicator of plant tolerance to heavy

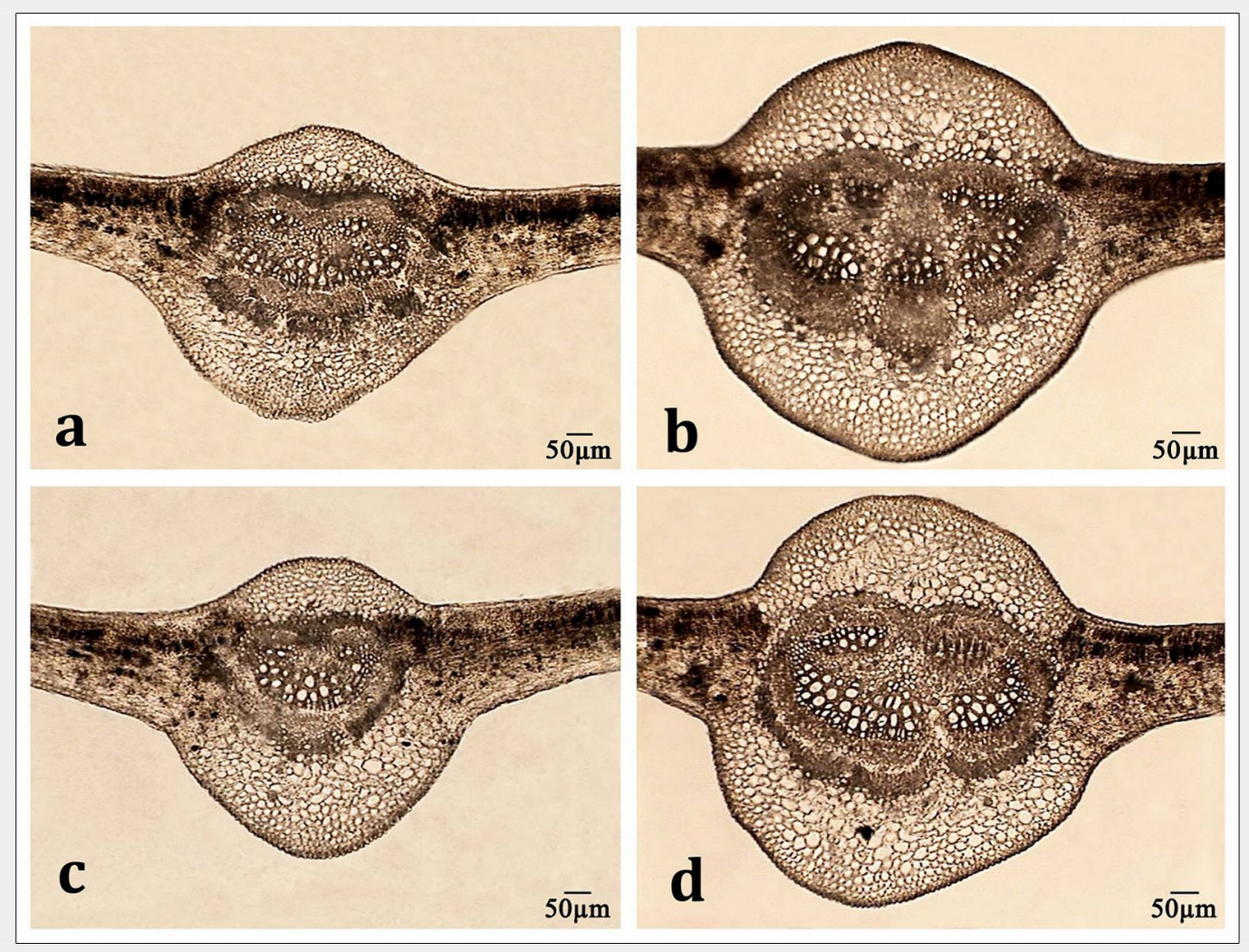

Fig. 1 - Effect of $C d$ on the main vein cross section of Populus $\times$ euramericana (a, c) and P. deltoides (b, d) plants grown in soil culture for six weeks. (a, b): control; (c, d): Cd treatment. 


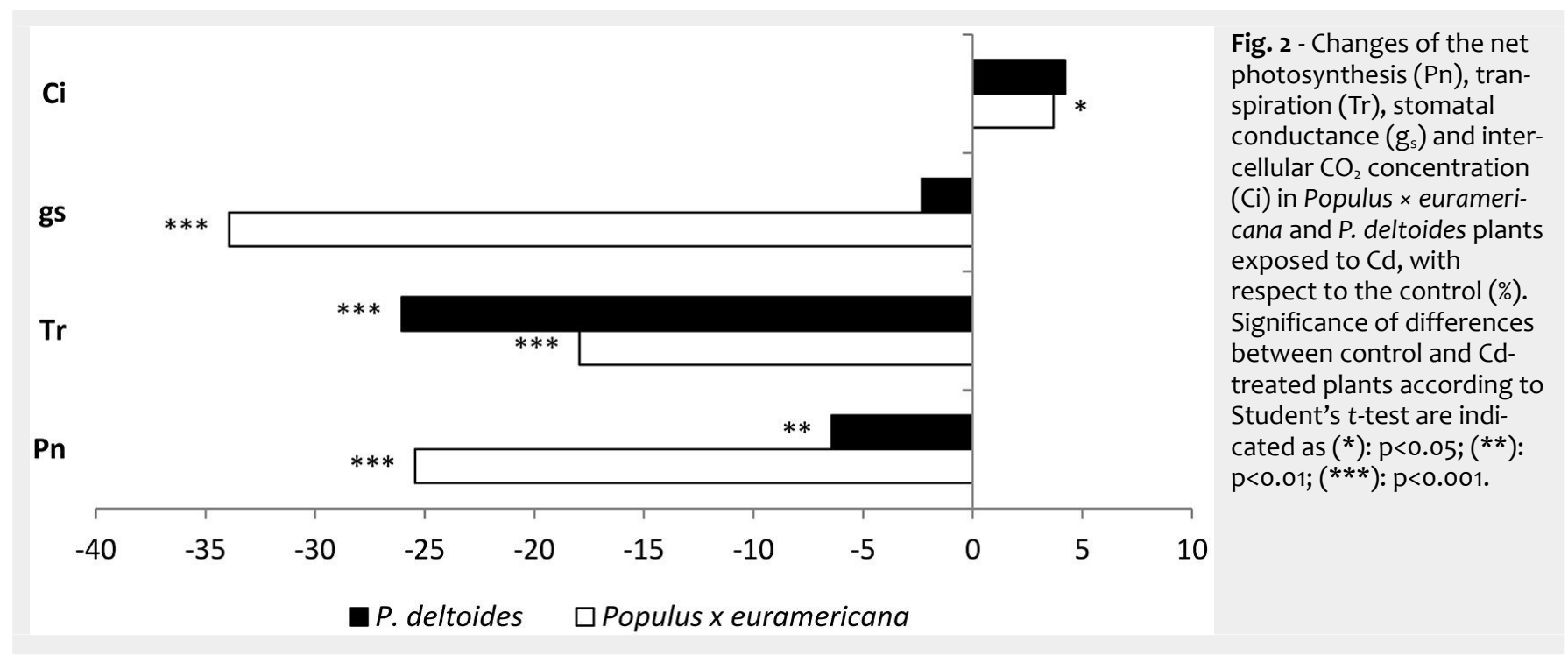

metals, which results from efficient mechanisms involved in the prevention of metal induced toxic effects (Tognetti et al. 2013). Means of light-saturated net assimilation at ambient $\mathrm{CO}_{2}$ levels $(\mathrm{Pn})$ and the rate of transpiration (Tr) of poplar clones investigated in the present study can be found in Pajević et al. (2009), who compared the photosynthetic activity of several poplar and willow clones exposed to various pollutants applied separately or in a cocktail. In the present study, relative changes of $\mathrm{Pn}, \mathrm{Tr}$, stomatal conductance $\left(\mathrm{g}_{\mathrm{s}}\right)$ and intercellular $\mathrm{CO}_{2}$ concentration $(\mathrm{Ci})$ were calculated (with respect to control) for $P$. deltoides and $P$. $\times$ euramericana plants exposed to $\mathrm{Cd}$ in the soil, in order to compare their photosynthetic performance with respect to phytoextraction potential. Parameters related to gas exchange were further correlated with biomass production (Fig. 2, Tab. 3).

The rate of photosynthesis was considerably decreased in Cd-exposed plants in both clones (25.5 and 6.4\% in Populus $x$ euramericana and $P$. deltoides respectively). Similarly, the rate of transpiration was also decreased in both genotypes, but to a greater extent in $P$. deltoides $(25.8 \%)$ than P. $\times$ euramericana (18.1\%). However, a considerable decrease of stomatal conductance $\left(g_{s}\right)$ was observed only in Cd-exposed Populus $\times$ euramericana clone. The decrease in $g_{s}$ observed in the present study might be related to stomatal closure or decrease of the stomatal aperture size, with concomitant limitations on the diffusion of water vapor and gasses $\left(\mathrm{CO}_{2}\right.$ and $\mathrm{O}_{2}$ ). A significant increase of intercellular $\mathrm{CO}_{2}$ concentrations, accompanied with a reduction of photosynthetic activity, was observed in both genotypes, while $g_{s}$ reduction occurred only in Populus $x$ euramericana. Considering the significant increase in intercellular $\mathrm{CO}_{2}$ concentration in both poplar clones, but differential $g_{s}$ response following $\mathrm{Cd}$ exposure, our results suggest different mechanisms (stomatal and/or mesophyll impairments) are in- volved in Cd-induced reduction of photosynthetic activity in the studied poplars. Reduction of net photosynthetic rate due to mesophyll limitations has been observed in other woody (Salicaceae - Vassilev et al. 2005) and herbaceous (Tang et al. 2015) species exposed to $\mathrm{Cd}$. However, the increase of intercellular $\mathrm{CO}_{2}$ levels observed in both clones (regardless of $g_{s}$ ) suggests inhibition of Calvin cycle enzymes rather than PSII activity in the tested clones (Pajević et al. 2009). Previous investigations reported negative effects of $\mathrm{Cd}$ on various enzymes of the Calvin cycle, for example ribulose-1.5-bisphosphate carboxylase/oxygenase (Chaffei et al. 2004), glyceraldehyde-3-phosphate dehydrogenase (GAPDH) and 3-phosphoglyceric acid kinase (Burzynski \& Zurek 2007). These conclusions may also apply for the poplars used in the present study, due to the discrepancy between anatomical characteristic and expected photosynthetic activity. Namely, the decrease in palisade cell size observed here in the Populus $x$ euramericana clone was expected to positively correlate with photosynthetic rate, since a decrease of mesophyll cell size results in an increase in area available for carbon dioxide diffusion and might contribute to higher photosynthetic efficiency (Ivanova \& P'yankov 2002).

In the present study, Cd significantly decreased the rate of transpiration in P. deltoides plants, without affecting stomatal conductance (Fig. 2), suggesting that the occurrence of structural changes in roots was triggered by $\mathrm{Cd}$ metal accumulation. Development of physical barriers in roots intended to restrict the entry of $\mathrm{Cd}$ into the xylem, and a concomitant decrease of $\mathrm{Cd}$ accumulation in shoot tissues, has been observed in various plant species (Lux et al. 2011). However, these changes might affect water uptake and transport as well as transpiration, due to the relationship between root permeability to water and the rate of transpiration. In Populus $\times$ euramericana clone, $\mathrm{Cd}$ treatment decreased both transpiration and stomatal conductance. Stomatal closure and alteration of stomatal conductance might be the result of the interaction of $\mathrm{Cd}$ at the guard cell level, or a consequence of toxic effects in other plant tissues, leading to impairment of water balance and subsequent stomatal closure (Perfus-Barbeoch et al. 2002). Cd-induced alterations of stomatal conductance and transpiration have been observed in other plant species (Pietrini et al. 2010, Liu et al. 2014). Since stomatal conductance was not found to be reduced by $\mathrm{Cd}$ exposure in the $P$. deltoides clone (in contrast to the Populus $\times$ euramericana clone which displayed a considerably lower $g_{s}-$ Fig. 2), unlimited diffusion of $\mathrm{CO}_{2}$ to the mesophyll cells is to be expected.

Translocation of $\mathrm{Cd}$ is related to energydependent uptake from the medium to the xylem, and transfer from the xylem to the leaves, which is driven mainly by transpiration (Liu et al. 2016). Although transpiration was higher in P. deltoides than Populus $x$ euramericana, it was reduced to a greater extent in P. deltoides following Cd exposure, and probably contributed to lower accumulation of $\mathrm{Cd}$ in the leaves of $P$. deltoides vs. P. $\times$ euramericana (Tab. 5). However, Akhter \& Macfie (2012) attributed greater importance to species-specific factors regulating internal plant distribution of Cd over transpiration rate, in Cd translocation to aboveground tissues.

The most readily observable symptom of perturbation of chlorophyll metabolism in plants experiencing the toxic effect of heavy metals is leaf chlorosis caused by decreased chlorophyll concentration due to enhanced degradation or reduced biosynthesis. In our experiment, chlorosis was not observed in young leaves of plants exposed to $\mathrm{Cd}$. Generally, higher concentrations of chlorophylls were recorded in $P$. deltoides than $P$. $\times$ euramericana clone, independent of $\mathrm{Cd}$ exposure (Tab. 6). Although Cd negatively affected the concentration of chlorophylls in both poplar clones, values were reduced to a greater 
Tab. 5 - Cadmium accumulation and translocation in Populus $\times$ euramericana and $P$. deltoides plants cultivated in soil culture without (control) or with ( $\mathrm{Cd}$ treat) $\mathrm{Cd}$. Values are mean \pm standard error. Means within a row followed by different letters are significantly different after Duncan's test $(P \leq 0.05)$. Two-way ANOVA $(n=3)$ was applied to evaluate coefficient of variation $(C V, \%)$, the clone effect, the $C d$ treatment effect $\left(C D\right.$ treat) and their interaction $(C l o n e \times C d) .\left(C d_{\text {roots }}, C d_{\text {stem }}, C d l_{\text {eaves }}\right)$ : concentration of $C d$ in roots,

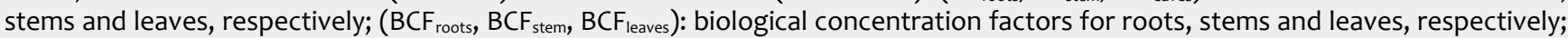
$\left(T f_{\text {stem }}, T f_{\text {leaves }}\right)$ : translocation factors for stem and leaves, respectively; $(*): p<0.05 ;(* *): p<0.01 ;(* * *): p<0.001 ;(n s): p>0.05$.

\begin{tabular}{|c|c|c|c|c|c|c|c|c|}
\hline \multirow[b]{2}{*}{ Parameter } & \multicolumn{2}{|c|}{ Populus $\times$ euramericana } & \multicolumn{2}{|c|}{ P. deltoides } & \multirow[b]{2}{*}{$\begin{array}{l}\text { CV } \\
(\%)\end{array}$} & \multicolumn{3}{|c|}{ ANOVA $P$ values } \\
\hline & Control & $\underset{\text { treat }}{\mathrm{Cd}}$ & Control & $\begin{array}{c}\mathrm{Cd} \\
\text { treat }\end{array}$ & & Clone & $\underset{\text { treat }}{\mathrm{Cd}}$ & $\begin{array}{l}\text { Clone } \\
\times \text { Cd }\end{array}$ \\
\hline $\mathrm{Cd}_{\text {roots }}\left(\mathrm{mg} \mathrm{kg}^{-1}\right)$ & $1.66 \pm 0.02^{d}$ & $10.13 \pm 0.06^{a}$ & $3.54 \pm 0.08^{c}$ & $5.19 \pm 0.10^{b}$ & 2.52 & $* * *$ & $* * *$ & $* * *$ \\
\hline $\mathrm{Cd}_{\text {stem }}\left(\mathrm{mg} \mathrm{kg}^{-1}\right)$ & $1.31 \pm 0.14^{c}$ & $3.17 \pm 0.04^{b}$ & $1.35 \pm 0.3^{c}$ & $4.43 \pm 0.06^{a}$ & 5.4 & $* * *$ & $* * *$ & $* * *$ \\
\hline $\mathrm{Cd}_{\text {leaves }}\left(\mathrm{mg} \mathrm{kg}^{-1}\right)$ & $1.03 \pm 0.06^{c}$ & $4.16 \pm 0.02^{a}$ & $0.77 \pm 0.10^{c}$ & $1.49 \pm 0.10^{b}$ & 7.6 & $* * *$ & $* * *$ & $* * *$ \\
\hline $\mathrm{BCF}_{\text {roots }}$ & $4.76 \pm 0.06^{b}$ & $1.24 \pm 0.01^{c}$ & $10.10 \pm 0.23^{a}$ & $0.64 \pm 0.01^{d}$ & 4.99 & $* * *$ & $* * *$ & $* * *$ \\
\hline $\mathrm{BCF}_{\text {stem }}$ & $3.73 \pm 0.40^{\mathrm{a}}$ & $0.39 \pm 0.00^{b}$ & $3.86 \pm 0.08^{a}$ & $0.54 \pm 0.01^{b}$ & 16.73 & ns & $* * *$ & ns \\
\hline $\mathrm{BCF}_{\text {leaves }}$ & $2.95 \pm 0.18^{a}$ & $0.51 \pm 0.00^{c}$ & $2.21 \pm 0.30^{b}$ & $0.18 \pm 0.01^{c}$ & 20.82 & * & $* * *$ & ns \\
\hline $\mathrm{Tf}_{\text {stem }}$ & $0.78 \pm 0.08^{a}$ & $0.31 \pm 0.01^{\mathrm{b}}$ & $0.38 \pm 0.02^{b}$ & $0.85 \pm 0.03^{a}$ & 12.8 & ns & ns & $* * *$ \\
\hline $\mathrm{Tf}_{\text {leaves }}$ & $0.62 \pm 0.05^{\mathrm{a}}$ & $0.41 \pm 0.00^{\mathrm{b}}$ & $0.22 \pm 0.03^{c}$ & $0.29 \pm 0.02^{c}$ & 14.37 & $* * *$ & ns & $* *$ \\
\hline
\end{tabular}

extent in Populus $x$ euramericana than $P$. deltoides: specifically, concentrations of chlorophyll $a, b$ and total chlorophylls decreased by $17.6 \%, 34.9 \%$ and $22.9 \%$ in Populus $\times$ euramericana, and by $16.2 \%, 31.3 \%$ and $20.8 \%$ P. deltoides, respectively as compared to control. These observations are in agreement with results obtained for other poplar clones cultivated in the presence of $\mathrm{Cd}$, including clones of Populus $\times$ euramericana, Populus $\times$ generosa, Populus $\times$ canadensis, Populus deltoides $\times$ P. nigra, P. deltoides, P. nigra, P. alba and P. trichocarpa (Pietrini et al. 2010, Zhang et al. 2014a).

In our study, chlorophyll concentration was determined in young leaves emerged from plants exposed to $\mathrm{Cd}$, indicating inhibition of biosynthesis rather than stimulated degradation in Populus $\times$ euramericana and $P$. deltoides. It has been suggested that $\mathrm{Cd}$ alters chlorophyll biosynthesis through disturbance of glutathione availability, inhibition of $\delta$-aminolevulinic acid dehydratase activity, disturbance of protochlorophyllide reductase function, interference with the uptake of other divalent cations (including calcium, magnesium and iron), or substitution of $\mathrm{Cd}$ for $\mathrm{Mg}$ in the chlorophyll molecule (Parmar et al. 2013). In our previous experiments on hydroponically cultivated poplars $(P$. deltoi- des cl. B-81, (P. nigra $\times$ P. maximowitzii $) \times P$. nigra var. Italica cl. 9111/93, and $P$. deltoides $\times$ P. nigra $\mathrm{Cl}$. M-1) exposed to various $\mathrm{Cd}$ concentrations, a considerable decrease in Fe concentration in aboveground plant organs (i.e., young leaves and shoots) was detected (Nikolić 2009). Therefore, we assume that the decreased chlorophyll content observed in Populus $x$ euramericana and $P$. deltoides plants exposed to $\mathrm{Cd}$ might be, at least partially, ascribed to $\mathrm{Fe}$ deficiency. Although $\mathrm{Cd}$ treatment considerably reduced the concentration of chlorophyll $a$ and $b$ in both Populus $\times$ euramericana and $P$. deltoides plants, the increase of chlorophyll $a / b$ ratio observed suggests $a$ greater reduction of chlorophyll $b$ concentration than chlorophyll $a$. A favored decrease of chlorophyll $b$ concentration could arise from either decreased conversion of chlorophyll $a$ to chlorophyll $b$, or increased reversion of chlorophyll $b$ to chlorophyll $a$ (Ebbs \& Uchil 2008). Considering that the light-harvesting chlorophyll-protein complex of photosystem II contains the majority of chlorophyll b (Kitajima \& Hogan 2003),the obtained results suggest that Cd causes a decrease in photosystem II (PSII) light harvesting complexes related to reaction centers (Liu et al. 2014).

The presence of $\mathrm{Cd}$ in the growth sub- strate considerably decreased the concentration of carotenoids in Populus $\times$ euramericana clones (by $14.4 \%$ vs. control - Tab. 6), in contrast with the results of Lunáčková et al. (2003), who found no influence of Cd treatment on total chlorophyll and carotenoid content in another Populus $\times$ euramericana clone. The decreased carotenoid content observed in plant species during $\mathrm{Cd}$ toxicity has been ascribed to a protective mechanism that preserves chlorophyll pools at the expense of carotenoids, due to overproduction of reactive oxygen species (ROS - Tang et al. 2015). Therefore, the increase in carotenoid concentrations observed under heavy metal stress contributes to cell protection against oxidative damage (Borowiak et al. 2015). Nevertheless, the concentration of carotenoids was not considerably changed in $P$. deltoides plants.

NR activity is considered to be the ratelimiting step in nitrogen $(\mathrm{N})$ assimilation in plants, due to the necessary reduction in the pathway nitrate - nitrite - ammonium prior to $\mathrm{N}$ incorporation into organic compounds. Poplar clones differ in NR activity due to their genetically determined ability to synthesize NR in response to nitrate ions. In our study, NR activity in leaves was considerably affected in Populus $\times$ eurame-

Tab. 6 - Photosynthetic pigments concentration, activity of nitrate reductase (NR), and concentration of proline in leaves of Populus $x$ euramericana and P. deltoides clones cultivated in soil culture without (control) or with (Cd treat) Cd. Values are mean \pm standard error. Means within a row followed by different letters are significantly different after Duncan's test ( $P \leq 0.05)$. Two-way ANOVA $(n=5)$ was applied to evaluate the coefficient of variation $(C V, \%)$, the clone effect, the $C d$ treatment effect and their interaction (Clone $\times(d) .(*): p<0.05 ;(* *): p<0.01 ;(* * *): p<0.001 ;(n s): p>0.05$

\begin{tabular}{|c|c|c|c|c|c|c|c|c|}
\hline \multirow[b]{2}{*}{ Parameters } & \multicolumn{2}{|c|}{ Populus $\times$ euramericana } & \multicolumn{2}{|c|}{ P. deltoides } & \multirow[b]{2}{*}{$\begin{array}{l}\text { CV } \\
\text { (\%) }\end{array}$} & \multicolumn{3}{|c|}{ ANOVA $P$ values } \\
\hline & Control & $\underset{\text { treat }}{\mathrm{Cd}}$ & Control & $\underset{\text { treat }}{\mathrm{Cd}}$ & & Clone & $\underset{\text { treat }}{\mathrm{Cd}}$ & $\begin{array}{l}\text { Clone } \\
\times \text { Cd }\end{array}$ \\
\hline Chlorophyll $a\left(\mathrm{mg} \mathrm{g}^{-1}\right)$ & $11.11 \pm 0.27^{b}$ & $9.16 \pm 0.63^{c}$ & $13.48 \pm 0.10^{a}$ & $11.30 \pm 0.02^{b}$ & 5.32 & $* * *$ & $* * *$ & ns \\
\hline Chlorophyll $b\left(\mathrm{mg} \mathrm{g}^{-1}\right)$ & $4.07 \pm 0.03^{b}$ & $2.65 \pm 0.09^{d}$ & $4.95 \pm 0.02^{a}$ & $3.40 \pm 0.12^{c}$ & 3.55 & $* * *$ & $* * *$ & ns \\
\hline Chlorophyll $a+b\left(\mathrm{mg} \mathrm{g}^{-1}\right)$ & $15.26 \pm 0.23^{b}$ & $11.77 \pm 0.73^{c}$ & $18.46 \pm 0.13^{a}$ & $14.61 \pm 0.14^{b}$ & 4.55 & *** & *** & ns \\
\hline Chlorophyll $a / b$ & $2.73 \pm 0.09^{b}$ & $3.45 \pm 0.12^{a}$ & $2.72 \pm 0.01^{b}$ & $3.33 \pm 0.11^{\mathrm{a}}$ & 5.16 & ns & *** & ns \\
\hline Carotenoids ( $\mathrm{mg} \mathrm{g}^{-1}$ ) & $3.26 \pm 0.12^{a}$ & $2.79 \pm 0.19^{b}$ & $3.62 \pm 0.04^{a}$ & $3.33 \pm 0.07^{\mathrm{a}}$ & 6.39 & $* *$ & * & ns \\
\hline$N R\left(\mu \mathrm{MNO}_{2} \mathrm{~g}^{-1} \mathrm{~h}^{-1}\right)$ & $0.21 \pm 0.01^{a}$ & $0.13 \pm 0.01^{b}$ & $0.14 \pm 0.01^{b}$ & $0.15 \pm 0.00^{b}$ & 9.44 & * & *** & $* * *$ \\
\hline Proline $\left(\mu \mathrm{g} \mathrm{g}^{-1}\right)$ & $21.84 \pm 1.29^{a}$ & $12.49 \pm 0.80^{b}$ & $14.4 \pm 0.93^{b}$ & $14.41 \pm 0.38^{b}$ & 9.98 & * & $* * *$ & $* * *$ \\
\hline
\end{tabular}


ricana, while in $P$. deltoides no significant changes were induced by the presence of $\mathrm{Cd}$ in the soil (Tab. 6). Significant changes of NR activity in both roots and leaves of $\mathrm{Cd}$ exposed plants with respect to the control were also found in the experiment with three poplar cultivars (Nikolić 2009). This discrepancy in NR enzyme activity in the leaves of Populus $x$ euramericana clones could be ascribed to the higher $C d$ concentrations measured in $P$. $\times$ euramericana leaves in our study (Tab. 5). Since the availability of nitrate ions, along with other mechanisms, enhances NR activity, the decreased NR activity observed in Populus $x$ euramericana leaves may be, at least partly, attributed to the depletion of a continuous supply of nitrates through the xylem via the transpiration stream (Kawachi et al. 2002). Furthermore, NR can also catalyze the reduction of nitrites to nitric oxide, a cell signaling molecule which plays an important role in plant responses to cadmium stress (Gill et al. 2013). Lowered NR activity in P. $\times$ euramericana plants suggests Cd-induced diminution of nitrogen $(\mathrm{N})$ delivery for assimilation into plant organic compounds. A sufficient $\mathrm{N}$ supply positively affects the tolerance of plants against $\mathrm{Cd}$ toxicity through increased biomass production (by improved photosynthetic capacity), soluble protein content, and activity of antioxidant enzymes, concomitantly with reduced $\mathrm{Cd}$ accumulation in plant organs (Sarwar et al. 2010, Nazar et al. 2012). Recent experiments indicate that nitrogen efficiently alleviates $\mathrm{Cd}$ toxicity in poplars, by unblocking the chlorophyll synthesis pathway and preventing the occurrence of toxicity symptoms (Zhang et al. 2014a). Higher NR activity accompanied by high $\mathrm{N}$ content and proline accumulation has been reported in Cdtolerant plants (Asgher et al. 2013). Therefore, $\mathrm{N}$ metabolism is pivotal to the response and acclimation of plants to heavy metal stress, because plant tolerance depends on the synthesis of diverse nitrogen containing metabolites, such as specific amino acids (proline, histidine), peptides (glutathione, phytochelatins), amines and mugineic acids (Sharma \& Dietz 2006). In our study, proline concentrations were higher in Populus $x$ euramericana than $P$. deltoides plants in the control treatment (Tab. 6). However, a significant decrease in proline content (from 21.84 to $12.49 \mu \mathrm{g} \mathrm{g}^{-1}$ in control and Cd treatment, respectively) was observed only in Populus $x$ euramericana clones under $\mathrm{Cd}$ exposure, consistent with previous investigations on poplars ( $\mathrm{Ni}$ kolić et al. 2008). This observed decrease in proline content in Populus $\times$ euramericana leaves might be explained by $\mathrm{Cd}$-induced $\mathrm{N}$ deficiency (lower NR activity), with consequent enhancement of proline degradation over synthesis. Increased proline synthesis under $\mathrm{Cd}$ exposure has been related to increased tolerance of various plant species, including poplars (Sharma \& Dietz 2006, He et al. 2013). Thus, we suppose that the unaffected proline content observed in $P$. deltoides plants under $C d$ stress indicates undisturbed $\mathrm{N}$ metabolism and contributes to the higher $\mathrm{Cd}$ tolerance (according to Ti - Tab. 2) of the P. deltoides clone versus $P$. $\times$ euramericana, along with other mechanisms.

\section{Phytoremediation potential: $\mathrm{Cd}$ accumulation, translocation and BCF}

The concentration and distribution of $\mathrm{Cd}$ in plant organs was noticeably different in $P$. deltoides and $P . \times$ euramericana plants cultivated in Cd-enriched soil (Tab. 5). The Populus $\times$ euramericana clone accumulated considerably more $\mathrm{Cd}$ in roots and leaves (10.13 and $4.16 \mathrm{mg} \mathrm{kg}^{-1}$, respectively) than the P. deltoides clone ( 5.19 and $1.49 \mathrm{mg} \mathrm{kg}^{-1}$, respectively). However, the Populus $\times$ euramericana clone accumulated significantly less $\mathrm{Cd}$ in stems than $P$. deltoides (3.17 and $4.43 \mathrm{mg} \mathrm{kg}^{-1}$, respectively). Previous studies have indicated that the transpiration stream is a driving force in translocation of $\mathrm{Cd}$ and its accumulation in leaves in various plant species (Vassilev et al. 2005, Liu et al. 2016), and our results are consistent with these reports. Although $P$. deltoides displayed a higher rate of transpiration than Populus $\times$ euramericana (regardless of $\mathrm{Cd}$ treatment), these values were significantly lower in treated plants in both studied clones by 25.8 and $18.1 \%$. Consequently, this lower transpiration reduced $\mathrm{Cd}$ accumulation in leaves to a greater extent in P. deltoides, resulting in higher $\mathrm{Cd}$ accumulation in stems, probably due to $\mathrm{Cd}$ retention (Liu et al. 2016). Based on a study addressing species-specific relationships between cadmium translocation and transpiration in various plant species, Akhter \& Macfie (2012) concluded that $\mathrm{Cd}$ accumulation in plants depends on multiple factors, including bulk flow through transpiration, $\mathrm{Cd}$ concentration in the growth substrate and a plant-specific factor. The results obtained in the present study suggest that both clones employ an exclusion strategy, by retaining the highest amounts of $\mathrm{Cd}$ in the roots and low translocation into aerial organs. However, P. deltoides plants accumulated more $C d$ in stems than P. $\times$ euramericana, suggesting its potential not only for phytostabilization, but also for phytoextraction projects.

Bioconcentration factors (BCF) calculated for aboveground (leaves, stem) plant organs and roots (Tab. 5) showed a narrow range of variation (0.18-1.24). BCF values decreased in both poplar clones with an increase in $\mathrm{Cd}$ concentration in the growth substrate. The tested poplar clones differed significantly only by root BCF values. The obtained results are in agreement with previous studies indicating higher BCF values in roots than aboveground organs in various poplar species, due to their differential ability to accumulate $\mathrm{Cd}$ ( $\mathrm{He}$ et al. 2013).

Translocation of $\mathrm{Cd}$ from roots to shoots and leaves was estimated by $\mathrm{Tf}_{\text {stem }}$ and
$\mathrm{TF}_{\text {leaves }}$ (Tab. 5). The clones showed specific patterns of $\mathrm{Cd}$ translocation in the treated plants. Under Cd exposure, Tf for both leaves and stems was considerably reduced in Populus $\times$ euramericana plants with respect to control. However, $\mathrm{TF}_{\text {leaves }}$ was unaffected, and $\mathrm{Tf}_{\text {stem }}$ significantly increased in P. deltoides plants exposed to $\mathrm{Cd}$ with respect to control. Furthermore, $T f_{\text {leaves }}$ was lower, while $\mathrm{Tf}_{\text {stem }}$ was higher in clone $P$. deltoides than $P$. $\times$ euramericana, which also exhibited higher tolerance (based on $\mathrm{Ti}$ ) than the latter clone. These results are in agreement with the findings of Vassilev et al. (2005), who conducted an experiment with two willow species grown hydroponically under increasing $\mathrm{Cd}$ concentrations and revealed greater allocation of $\mathrm{Cd}$ to leaves in less-tolerant species. The obtained results suggest that different strategies for metal distribution are employed by the tested poplars under $\mathrm{Cd}$ stress. Following treatment, 58.0 and $46.7 \%$ of the total Cd content was accumulated in the roots of Populus $x$ euramericana and $P$. deltoides, respectively, with the remainder in the stems (18.2 and 39.9\%) and leaves (23.8 and $13.4 \%$ ).

\section{Conclusion}

Efficient decontamination of $\mathrm{Cd}$ polluted soils through phytoremediation requires fast growing tree species with high $\mathrm{Cd}$ tolerance and the ability to preferentially accumulate $\mathrm{Cd}$ in aboveground plant organs. The higher accumulation of $\mathrm{Cd}$ observed in stems rather than leaves of poplar plants is advantageous for prevention of secondary pollution of the environment due to autumnal shedding and spreading of $\mathrm{Cd}$ enriched leaves. In the present study, morphological, anatomical and physiological data suggest that Populus $\times$ euramericana and $P$. deltoides clones respond differently to $\mathrm{Cd}$ exposure. According to our results, P. deltoides plants exposed to $\mathrm{Cd}$ display higher tolerance, undisturbed $\mathrm{N}$ metabolism and increased $\mathrm{Cd}$ translocation to stems versus $P . \times$ euramericana. Thus, this $P$. deltoides clone may have potential for both phytostabilization and phytoextraction projects. The screening protocol outlined in the present study is based on physiological and morphological plant characteristics, and may represent an efficient method for evaluating crop performance and tolerance to heavy metal stress.

\section{Acknowledgements}

This study was supported by the Ministry of Education, Science and Technological Development of the Republic of Serbia. All authors have been involved in designing the experiment, cultivation of plants, measurement of studied parameters, processing and discussion of obtained results, and writing the manuscript. The authors have no conflicts of interest. The authors wish to express their appreciation to Dr. Edward Petri, for editing this manuscript for English language and style. We are also grate- 
ful to both anonymous reviewers for valuable and constructive suggestions and comments.

\section{References}

Aasamaa K, Heinsoo K, Holm B (2010). Biomass production, water use and photosynthesis of Salix clones in a wastewater purification system. Biomass and Bioenergy 34: 897-905. - doi: 10.1016/j.biombioe.2010.01.035

Akhter F, Macfie SM (2012). Species-specific relationship between transpiration and cadmium translocation in lettuce, barley and radish. Journal of Plant Studies 1: 1-13.

Al Afas N, Marron N, Ceulemans R (2007). Variability in Populus leaf anatomy and morphology in relation to canopy position, biomass production, and varietal taxon. Annals of Forest Science 64: 521-532. - doi: 10.1051/forest:2007029 Asgher M, Khan MIR, Iqbal N, Masood A, Khan NA (2013). Cadmium tolerance in mustard cultivars: dependence on proline accumulation and nitrogen assimilation. Journal of Functional and Environmental Botany 3: 30-42. - doi: 10.5958/j.2 231-1750.3.1.005

Bates LS (1973). Rapid determination of free proline for water stress studies. Plant and Soil 39: 205-207. - doi: 10.1007/BFo0018060

Bernardini A, Salvatori E, Guerrini V, Fusaro L, Canepari S, Manes F (2016a). Effects of high Zn and $\mathrm{Pb}$ concentrations on Phragmites australis (Cav.) Trin. Ex. Steudel: photosynthetic performance and metal accumulation capacity under controlled conditions. International Journal of Phytoremediation 18: 16-24. - doi: 10.1080/152 26514.2015.1058327

Bernardini A, Salvatori E, Di Re S, Fusaro L, Nervo G, Manes F (2016b). Natural and commercial Salix clones differ in their ecophysiological response to Zn stress. Photosynthetica 54: 5664. - doi: 10.1007/s11099-015-0155-9

Borowiak K, Gasecka M, Mleczek M, Dabrowski J, Chadzinikolau T, Magdziak Z, Golinski P, Rutkowski P, Kozubik T (2015). Photosynthetic activity in relation to chlorophylls, carbohydrates, phenolics and growth of a hybrid Salix purpurea $x$ triandra $x$ viminalis 2 at various $Z n$ concentrations. Acta Physiologiae Plantarum 37 (8): 599. - doi: 10.1007/s11738-015-1904-X

Burzynski M, Zurek A (2007). Effects of copper and cadmium on photosynthesis in cucumber cotyledons. Photosynthetica 45: 239-244. - doi: 10.1007/s11099-007-0038-9

Chaffei C, Pageau K, Suzuki A, Gouia H, Ghorbel $\mathrm{MH}$, Masclaux-Daubresse C (2004). Cadmium toxicity induced changes in nitrogen management in Lycopersicon esculentum leading to a metabolic safeguard through an amino acid storage strategy. Plant and Cell Physiology 45: 1681-1693. - doi: 10.1093/pcp/pch192

Dandekar AM, Uratsu SL (1988). A simple base pair change in proline biosynthesis genes causes osmotic stress tolerance. Journal of Bacteriology 170: 5943-5945. - doi: 10.1128/jb.1 70.12.5943-5945.1988

Djebali W, Zarrouk M, Brouquisse R, El Kahoui S, Liamam F, Ghorbel MH, Chaïbi W (2005). Ultrastructure and lipid alterations induced by cadmium in tomato (Lycopersicon esculentum) chloroplast membranes. Plant Biology 7: 358368. - doi: 10.1055/s-2005-837696
Ebbs S, Uchil S (2008). Cadmium and zinc induced chlorosis in Indian mustard [Brassica juncea (L.) Czern] involves preferential loss of chlorophyll b. Photosynthetica 46: 49-55. - doi: 10.1007/s11099-008-0010-3

European Union (2002). Heavy metals in wastes. Project ENV.E.3/ETU/2000/0058 Final Report, European Commission on Environment, DG ENV. E3, COWI A/S, Denmark, pp. 86.

Gill SS, Hasanuzzaman M, Nahar K, Macovei A, Tuteja N (2013). Importance of nitric oxide in cadmium stress tolerance in crop plants. Plant Physiology and Biochemistry 63: 254-261. - doi: 10.1016/j.plaphy.2012.12.001

Hageman RH, Reed AJ (1980). Nitrate reductase from higher plants. Methods in Enzimology 69: 270-279. - doi: 10.1016/Soo76-6879(80)69026-0 He J, Ma C, Ma Y, Li H, Kang J, Liu T, Polle A, Peng C, Luo Z-B (2013). Cadmium tolerance in six poplar species. Environmental Science and Pollution Research 20: 163-174. - doi: 10.1007/s11 356-012-1008-8

Ivanova LA, P'yankov VI (2002). Structural adaptation of the leaf mesophyll to shading. Russian Journal of Plant Physiology 49: 419-431. - doi: 10.1023/A:1015513607202

Kawachi T, Shoji Y, Sugimoto T, Oji YL, Kleinhofs A, Warner RL, Ohtake N, Ohyama T, Sueioshi K (2002). Role of xylem sap nitrate in regulation of nitrate reductase gene expression in leaves of barley (Hordeum vulgare L.) seedlings. Soil Science and Plant Nutrition 48: 79-85. - doi: 10.1080/00380768.2002.10409174

Kitajima K, Hogan KP (2003). Increases of chlorophyll $\mathrm{a} / \mathrm{b}$ ratios during acclimation of tropical woody seedlings to nitrogen limitation and high light. Plant, Cell and Environment 26: 857865. - doi: 10.1046/j.1365-3040.2003.01017.x

Liu H, Wang H, Ma Y, Wang H, Shi Y (2016). Role of transpiration and metabolism in translocation and accumulation of cadmium in tobacco plants (Nicotiana tabacum L.). Chemosphere 144: 1960-1965. - doi: 10.1016/j.chemosphere.201 5.10 .093

Liu L, Sun H, Chen J, Zhang Y, Li D, Li C (2014). Effects of cadmium (Cd) on seedling growth traits and photosynthesis parameters in cotton (Gossypium hirsutum L.). Plant Omics Journal 7 (4): 284-290. [online] URL: http://www.cabdi rect.org/cabdirect/abstract/20143294146

Luković J, Merkulov L, Pajević S, Zorić L, Nikolić N, Borišev M, Karanović D (2012). Quantitative assessment of effects of cadmium on the histological structure of poplar and willow leaves. Water, Air and Soil Pollution 223: 2979-2993. doi: 10.1007/s11270-012-1081-0

Lunáčková L, Šottnikova A, Masarovičova E, Lux A, Streško V (2003). Comparison of cadmium effect on willow and poplar in response to different cultivation conditions. Biologia Plantarum 47: 403-411. - doi: 10.1023/B:BIOP.000002 3884.54709.09

Lux A, Martinka M, Vaculík M, White PJ (2011). Root responses to cadmium in the rhizosphere: a review. Journal of Experimental Botany 62: 21-37. - doi: 10.1093/jxb/erq281

Lux A, Sottníková A, Opatrná J, Greger M (2004). Differences in structure of adventitious roots in Salix clones with contrasting characteristics of cadmium accumulation and sensitivity. Physiologia Plantarum 120: 537-545. - doi: 10.1111/j.00 31-9317.2004.0275.x

Nazar R, Iqubal N, Masood A, Khan MIR, Syeed S, Khan NA (2012). Cadmium toxicity in plants and role of mineral nutrients in its alleviation. American Journal of Plant Sciences 3: 14761489. - doi: 10.4236/ajps.2012.310178

Nikolić N (2009). Effect of heavy metals on morpho-anatomical and physiological characteristics of poplar clones (Populus spp.). PhD thesis, Faculty of Sciences, University of Novi Sad, Republic of Serbia, pp. 92-94.

Nikolić N, Kojić D, Pilipović A, Pajević S, Krstić B, Borišev M, Orlović S (2008). Responses of hybrid poplar to cadmium stress: photosynthetic characteristics, cadmium and proline accumulation, and antioxidant enzyme activity. Acta Biologica Croatica Series Botanica 50/2: 95-103. Pajević S, Borišev M, Nikolić N, Krstić B, Pilipović A, Orlović S (2009). Phytoremediation capacity of poplar (Populus spp.) and willow (Salix spp.) clones in relation to photosynthesis. Archives of Biological Sciences 61: 239-247. [online] URL: http://www.doiserbia.nb.rs/img/doi/0354-466 4/2009/0354-46640902239P.pdf

Parmar P, Kumari N, Sharma V (2013). Structural and functional alterations in photosynthetic apparatus of plants under cadmium stress. Botanical Studies 54: 45-50. - doi: 10.1186/1999-311054-45

Perfus-Barbeoch L, Leonhardt N, Vavasseur A, Forestier C (2002). Heavy metal toxicity: cadmium permeates through calcium channels and disturbs the plant water status. The Plant Journal 32: 539-548. - doi: 10.1046/j.1365-313X.2002. 01442.x

Pietrini F, Zacchini M, lori V, Pietrosanti L, Bianconi D, Massacci A (2010). Screening of poplar clones for cadmium phytoremediation using photosynthesis, biomass and cadmium content analyses. International Journal of Phytoremediation 12: 105-120. - doi: 10.1080/15226510902767 163

Sarwar N, Saifullah X, Malhi SS, Zia MH, Naeem A, Bibi S, Farid G (2010). Role of mineral nutrition in minimizing cadmium accumulation by plants. Journal of the Science of Food and Agriculture 90: 925-937. - doi: 10.1002/jsfa.3916

Sharma SS, Dietz KJ (2006). The significance of amino acids and amino acid-derived molecules in plant responses and adaptation to heavy metal stress. Journal of Experimental Botany 57: 711-726. - doi: 10.1093/jxb/erj073

Shi GR, Cai QS (2008). Photosynthetic and anatomic responses of peanut leaves to cadmium stress. Photosynthetica 46: 627-630. - doi: 10.1007/s11099-008-0107-8

Stoláriková-Vaculíková $\mathrm{M}$, Romeo S, Minnocci A, Luxová M, Vaculík M, Sebastiani L (2015). Anatomical, biochemical and morphological responses of poplar Populus deltoides clone Lux to $\mathrm{Zn}$ excess. Environmental and Experimental Botany 109: 235-243. - doi: 10.1016/j.envexpbot. 2014.07.001

Tang Y, Bao Q, Tian G, Fu K (2015). Heavy metal cadmium tolerance on the growth characteristics of industrial hemp (Cannabis sativa L.) in China. In: Proceedings of the "International Conference on Advances in Energy, Environment and Chemical Engineering (AEECE-2015)" (Chen S, Zhou S eds). Changsha (China) 26-27 Sept 2015. Atlantis Press, Amsterdam - Beijing - 
Paris, pp. 289-295.

Tognetti R, Cocozza C, Marchetti M (2013). Shaping the multifunctional tree: the use of Salicaceae in environmental restoration. iForest Biogeosciences and Forestry 6 (1): 37-47. - doi: 10.3832/iforog20-006

Vassilev A, Perez-Sanz A, Semane B, Carleer R, Vangrosveld J (2005). Cadmium accumulation and tolerance of two Salix genotypes hydroponically grown in presence of cadmium. Journal of Plant Nutrition 28: 2159-2177. - doi: 10.108 o/01904160500320806

Von Wettstein D (1957). Chlorophyll-letale und der submikroskopische formwechsel der plastiden [Chlorophyll and the submicroscopic shape change of plastid]. Experimental Cell Research 12: 427-433. [in German] - doi: 10.1016/00144827(57)90165-9

Wilkins DA (1978). The measurement of tolerance to edaphic factors by means of root growth. New Phytologist 80: 623-633. - doi: 10.1111/j.1469-8137.1978.tbo1595.x
Zhang F, Wan X, Zhong Y (2014a). Nitrogen as an important detoxification factor to cadmium stress in poplar plants. Journal of Plant Interactions 9: 249-258. - doi: 10.1080/17429145.2013.81 9944

Zhang X, Gao B, Xia H (2014b). Effect of cadmium on growth, photosynthesis, mineral nutrition and metal accumulation of bana grass and vetiver grass. Ecotoxicology and Environmental Safety 106: 102-108. - doi: 10.1016/j.ecoenv.2014. 04.025 